\title{
HYBRIDS VARIATION AND WHEAT STRAW MULCH EFFECTS ON VEGETATIVE GROWTH AND FRUIT YIELD OF SWEET PEPPER UNDER EL-ARISH AREA CONDITIONS
}

\author{
Eman A.G. Mohamed", S.A. Abo El-Kasem ${ }^{1}$; M.I. Mahmoud ${ }^{2}$, and A.I. El-Kassas ${ }^{2}$ \\ 1. Dept. Self-Pollinated Veg., Inst. Hort., Cent. Agric. Res., Egypt. \\ 2. Dept. Plant Prod., Fac. Environ Agric. Sci., Arish Univ., Egypt.
}

\begin{abstract}
Field experiments were carried out during the two summer seasons of 2016 and 2017 at The Experimental Farm, Faculty of Environmental Agricultural Sciences, Arish University, North Sinai, Egypt to study the effect of mulch (without mulch and straw mulch) on two colored sweet pepper hybrids ("Yellow Star F1" and "Red Star F1", Capsicum annuum L.). Transplanting was carried out on $19^{\text {th }}$ May. Straw mulch was added after 10 days later. The experimental plot area was $15 \mathrm{~m}^{2}$ (15 m long and $1.0 \mathrm{~m}$ wide). Drip irrigation system was used. Each experimental plot had one dripper line, the distance between plants in the same row was $50 \mathrm{~cm}$, which gave, planting density of 2.0 plants $\mathrm{m}^{-2}$. Split -plot design with three replicates was used, where sweet pepper hybrids were randomly arranged in the main plots, and mulch treatments were randomly arranged in the sub plots. 'Red Star F1' hybrid recorded the highest values of plant height, number of leaves and leaf area as well as plant fresh and dry weight traits at 75 days after transplanting in both seasons. Red Star F1'and Yellow Star F1' both with mulch recorded the highest values of all vegetative growth traits and marketable yield traits in both seasons. Mulch treatment had higher values of all studied marketable yield traits (number of fruits/plant, mean fruit weight $(\mathrm{g})$, and yield/plant $(\mathrm{kg})$ in both seasons. Using straw mulch increased number of fruits/plant by $48.59 \%$ as compared to without mulch treatment. The highest values of all marketable yield traits in both seasons were recorded with 'Red Star F1' or 'Yellow Star F1' both with mulch.
\end{abstract}

Key words: Hybrids, mulch, marketable yield, sweet pepper.

\section{INTRODUCTION}

Sweet pepper is a high value crop and rich in vitamins, particularly provitamin a, vitamin $\mathrm{B}$, vitamin $\mathrm{C}$ and minerals such as $\mathrm{Ca}, \mathrm{P}, \mathrm{K}$ and $\mathrm{Fe}$ (Malik et al., 2011). It also contains thiamine, vitamin $\mathrm{B} 6$, beta carotene, and folic acid. It is grown for green, spices, condiments, sauces and pickles. During the growth stages of pepper, many unfavorable environmental conditions occur such as high temperature and high radiation in particular during summer season. These particular conditions may exert a negative effect on plant growth and yield (López-Marín et al., 2011). In El-Arish region, irrigation depends on underground water with limited resources and high salinity. The main problem that influences fruit yield and quality of colored sweet pepper in summer season is the high solar radiation and high temperature. To overcome these problems it is necessary to protect plants from high solar radiation and high temperatures besides lowering water evaporation. Mulching aids in the control of temperature fluctuations (Dilipkumar et al., 1990). Studies conducted by Nkansah

\footnotetext{
* Corresponding author: Tel.: +20167808391

E-mail address: emanadelsam95@yahoo.com
} 
et al. (2003) showed that organic mulches (grass straw, rice straw, rice husk and sawdust) were more effective in reducing soil temperature compared to the control. Gandhi and Bains (2006) reported that mulches moderate hydrothermal regime of the soil and modify the microclimate by modifying soil temperature. Norman et al. (2011) found that dry Panicum maximum grass and sawdust mulches reduced soil temperature.

Thakur et al. (2000) reported higher plant height and number of leaves of pepper under Lantana leaves and grass mulches compared to un-mulched treatments. Plant height was significantly higher with the application of Glyricidia loppings used as mulch over no mulch control plots. However, it was at par with application of crop residue mulch (grasses/plant materials/ weeds) as reported by Venkanna (2008). Pepper plant height was significantly higher on grass mulch plots compared to the control (Dauda, 2011). In a pot on chilli plant experiment the greater number of leaves and plant height were recorded in rice straw mulch followed by wheat straw mulch and sugarcane bagasse mulch, while control plants recorded the lowest values (Iftikhar et al., 2011). Mulches had significant primitive effects on root elongation. This might be due to the conservation of enough soil moisture, suitable soil temperature as well as suitable microclimate condition (Norman et al., 2011).

Sugarcane bagasse mulch recorded the maximum pepper fruit length and width, followed by wheat straw mulch and rice straw mulch, while un-mulched treatment recorded the lowest one (Iftikhar et al., 2011). Therefore, the objectives of this work were to evaluate the effect of organic mulch (wheat straw) on two colored sweet pepper hybrids for vegetative growth and fruit yield under El Arish conditions.

\section{MATERIALS AND METHODS}

Field experiments were carried out during the two summer seasons of 2016 and 2017 at The Experimental Farm, Faculty of Environmental Agricultural Sciences, Arish University, North Sinai, Egypt to study the effect of wheat straw mulch (without mulch and straw mulch) on two colored sweet pepper hybrids ("Yellow Star F1" and "Red Star F1" Capsicum annuum L.). Seeds were sown in plastic seedling trays on $28^{\text {th }}$ March in both seasons. Transplanting was carried out on $19^{\text {th }}$ May. Straw mulch was added after 10 days later. The experimental plot area was $15 \mathrm{~m}^{2}$ (15 m long and $1.0 \mathrm{~m}$ wide). Drip irrigation system was used. Each experimental plot had one dripper line, the distance between the plants in the same row was $50 \mathrm{~cm}$, which gave planting density of 2.0 plants $\mathrm{m}^{-2}$.The physical and chemical analyses of the experimental soil and irrigation water are shown in Tables 1 and 2 , respectively.

The experiment consists of two factors, the first factor was two sweet pepper hybrids "Yellow Star F1" and "Red Star F1" and the second factor was two types of mulch (without mulch and straw mulch). So, the experiment included the following treatments:

1. Yellow Star F1 + without mulch,

2. Yellow Star F1 + with mulch,

3. Red Star F1 + without mulch, and

4. Red Star F1 + with mulch.

The treatments were arranged in a split plot design with three replicates, where sweet pepper hybrids were randomly arranged in the main plots, and mulch treatments were randomly arranged in the sub plots. The normal agricultural practices were carried out as commonly followed in ElArish region. 
SINAI Journal of Applied Sciences (ISSN: 2314-6079), Vol. (7), Is. (3), Dec. 2018

Table 1. Initial physical and chemical properties of investigated soil of cultivated area.

\begin{tabular}{|c|c|c|}
\hline \multicolumn{3}{|c|}{ Particles size distribution (\%) } \\
\hline & 2016 & 2017 seasons \\
\hline Coarse sand\% & 58.0 & 59.5 \\
\hline Fine sand $\%$ & 19.8 & 19.3 \\
\hline Silt \% & 12.9 & 13.0 \\
\hline Clay\% & 9.3 & 9.3 \\
\hline Soil texture & Loamy sand & Loamy sand \\
\hline Bulk density $\left(\mathrm{Mgm}^{-1}\right)$ & 1662 & 1661 \\
\hline \multicolumn{3}{|c|}{ Chemical properties soluble ions ( in $1: 5$ soil water extract) } \\
\hline $\mathrm{Ca}^{+}\left(\mathrm{meq}^{-1}\right)$ & 3.90 & 3.90 \\
\hline $\operatorname{Mg}^{+}\left(\mathbf{m e q}^{1}\right)$ & 3.62 & 3.43 \\
\hline $\mathrm{Na}^{+}\left(\mathrm{meq}^{-1}\right)$ & 2.54 & 2.59 \\
\hline $\mathrm{K}^{+}\left(\mathrm{meq}^{-1}\right)$ & 0.34 & 0.32 \\
\hline $\operatorname{CO3}^{-}\left(\mathrm{meq}^{-1}\right)$ & - & - \\
\hline $\operatorname{HCO3}^{-}\left(\mathrm{meq}^{-1}\right)$ & 4.30 & 4.40 \\
\hline $\mathrm{Cl}^{-}\left(\mathrm{meq}^{-1}\right)$ & 4.70 & 4.35 \\
\hline $\mathrm{SO}_{4}\left(\mathrm{meq}^{-1}\right)$ & 1.50 & 1.45 \\
\hline $\mathrm{EC}\left(\mathrm{dSm}^{-1}\right)$ in $1: 5$ water extract $)$ & 0.08 & 1.02 \\
\hline PH (in1:2.5 Soil water suspension extract) & 8.10 & 8.13 \\
\hline Organic matter $(\%)$ & 0.153 & 0.171 \\
\hline CaCo $3(\%)$ & 22.43 & 22.48 \\
\hline
\end{tabular}

Table 2. Chemical composition of irrigation water.

\begin{tabular}{|c|c|c|c|c|c|c|c|c|c|}
\hline \multirow[t]{3}{*}{$\mathbf{P H}$} & \multirow[t]{3}{*}{$\mathrm{ECm}^{-2}$} & \multicolumn{8}{|c|}{ Soluble ions(me l-1) } \\
\hline & & \multicolumn{4}{|c|}{ Cations } & \multicolumn{4}{|c|}{ Anions } \\
\hline & & $\mathrm{Ca}++$ & $\mathrm{Mg}++$ & $\mathbf{N a}+$ & $\mathbf{K +}$ & Cl- & $\mathrm{HCO3}^{-}$ & $\mathrm{CO3}^{--}$ & $\mathrm{SO4}^{--}$ \\
\hline \multicolumn{10}{|c|}{ First season (2016) } \\
\hline 7.55 & 5.93 & 20.50 & 16.80 & 18.50 & 0.24 & 45.92 & 2.90 & - & 7.22 \\
\hline \multicolumn{10}{|c|}{ Second season(2017) } \\
\hline 7.60 & 6.00 & 21.00 & 17.00 & 18.80 & 0.25 & 46.75 & 2.97 & - & 7.28 \\
\hline
\end{tabular}




\section{Data Recorded}

Five plants from each experimental unite were randomly taken after 75 days from transplanting to determined plant height $(\mathrm{cm})$, number of leaves, fresh and dry weights of plant. Leaf area was determined according to the method described by Ackley (1964). Fruits of all pickings tell the end of the experiment were counted and weighed and the following data were calculated: a) marketable yield, b) unmarketable yield (physiological disorders, especially blossom end rot and sunscald fruits).

\section{Statistical Analysis}

The obtained data were subjected to statistical analysis of variance according to Snedecor and Cochran (1980), and means separation was done according to Duncan (1958). Mstat C program was used for analysis.

\section{RESULTS AND DISCUSSION}

\section{Effect of Hybrid Variations}

\section{Vegetative growth}

Table 3 Show significant effects for hybrids on plant height, number of leaves and leaf area as well as plant fresh and dry weight traits at 75 days after transplanting in both seasons. 'Red Star F1' hybrid recorded the highest values in all studied traits except number of leaves/plant in both seasons. The 'Red Star F1' was more responsible to microclimate conditions around the plant than 'Yellow Star F1', this was reflected on expression of genes and their stability under the same studied conditions.

\section{Fruit yield}

Results presented in Tables 4 and 5 indicate that hybrids had no significant effects on all total marketable yield traits, except fruit yield $/ \mathrm{m}^{2}$ in the second season. 'Red Star F1' cultivar recorded the highest values. However, hybrids had no significant effect on all un-marketable yield traits, except number of fruits/plant, and fruit yield/plant in both seasons (Table 5). 'Red Star F1' hybrid recorded the highest values in all studied traits in both seasons. Using straw mulch increased number of fruits/ plant by $48.59 \%$ as compared to without mulch treatment.The increase in fruit yield of "Red Star F" may be due to the increase in leaf area per plant which increased the accumulation of dry matter in pepper leaves that help in the flowering process, fruit set and composition of fruits, consequently caused increase in fruit yield.

\section{Effect of Organic Mulch}

\section{Vegetative growth}

Results in Table 3 show significant effects for mulch treatments on plant height, number of leaves, leaf area, as well as fresh and dry weight traits at 75 days after transplanting. The highest values were recorded with mulch treatment in both seasons. These results may be due to the effect of organic mulch that maintain soil moisture and consequently resulted in good conditions for plant growth under high solar radiation and high temperature besides the high water salinity, hence, resulted in the maximum vegetative growth (maximum plant height, number of leaves and leaf area).

In addition, results agree with the findings of many researchers with organic mulch on different vegetable crops. Thakur et al. (2000) reported higher plant height of capsicum under lantana leaves and grass mulches compared to un-mulched treatments. Venkanna (2008) observed increase in chilli leaf area and leaf area index under glyricidia mulch and crop residue mulch over no mulch treatment. Dauda (2011) found that the highest plant height and number of pepper leaves at 10 weeks after plating was significantly higher with grass mulch plots compared to the control. Iftikhar et al. (2011) observed that organic 
SINAI Journal of Applied Sciences (ISSN: 2314-6079), Vol. (7), Is. (3), Dec. 2018

Table 3. Effect of hybrid variations and mulch on plant height, number of leaves, leaf area, fresh and dry weight of sweet pepper plant at 75 days after transplanting in 2016 and 2017 seasons.

\begin{tabular}{|c|c|c|c|c|c|c|}
\hline $\begin{array}{r}\text { T } \\
\text { Treatment }\end{array}$ & Parameter & $\begin{array}{c}\text { Plant } \\
\text { height }(\mathrm{cm})\end{array}$ & $\begin{array}{l}\text { Number of } \\
\text { leaves/plant }\end{array}$ & $\begin{array}{c}\text { Leaf area } \\
\left(\mathrm{m}^{2}\right)\end{array}$ & $\begin{array}{l}\text { Plant fresh } \\
\text { weight (g) }\end{array}$ & $\begin{array}{l}\text { Plant dry } \\
\text { weight (g) }\end{array}$ \\
\hline & & \multicolumn{5}{|c|}{ First season (2016) } \\
\hline \multirow{2}{*}{ Hybrids } & Yellow Star & $63.25 \mathrm{~b}$ & $95.19 \mathrm{a}$ & $23.73 b$ & $182.80 \mathrm{~b}$ & $51.35 b$ \\
\hline & Red Star & $65.82 \mathrm{a}$ & $90.89 \mathrm{a}$ & $28.32 \mathrm{a}$ & $199.05 \mathrm{a}$ & $54.61 \mathrm{a}$ \\
\hline \multirow{3}{*}{ Mulch } & Without & $60.77 b$ & $78.16 \mathrm{~b}$ & $21.189 b$ & $159.23 b$ & $46.54 b$ \\
\hline & With & $69.30 \mathrm{a}$ & $107.91 \mathrm{a}$ & $30.87 \mathrm{a}$ & $225.33 a$ & $95.38 \mathrm{a}$ \\
\hline & & \multicolumn{5}{|c|}{ Second season (2017) } \\
\hline \multirow{2}{*}{ Hybrids } & Yellow Star & $72.03 b$ & $98.87 \mathrm{a}$ & $20.70 \mathrm{~b}$ & $188.31 b$ & $58.34 \mathrm{~b}$ \\
\hline & Red Star & $74.81 \mathrm{a}$ & $94.10 \mathrm{a}$ & $24.84 \mathrm{a}$ & $204.95 \mathrm{a}$ & $60.35 \mathrm{a}$ \\
\hline \multirow{2}{*}{ Mulch } & Without & $65.27 \mathrm{~b}$ & $82.06 \mathrm{~b}$ & $19.98 b$ & $166.13 b$ & $49.64 b$ \\
\hline & With & $75.57 \mathrm{a}$ & $111.81 \mathrm{a}$ & $25.57 \mathrm{a}$ & $231.22 \mathrm{a}$ & $65.05 \mathrm{a}$ \\
\hline
\end{tabular}

Values having the same alphabetical letter(s) did not significantly differ at 0.05 level of probability according to Duncan's multiple range test.

Table 4. Effect of hybrid variations and mulch on marketable yield of sweet pepper in 2016 and 2017 seasons.

\begin{tabular}{cccccc}
\hline Treatment & Parameter & $\begin{array}{c}\text { Number of } \\
\text { fruits/plant }\end{array}$ & $\begin{array}{c}\text { Mean fruit } \\
\text { weight (g) }\end{array}$ & $\begin{array}{c}\text { Yield/plant } \\
(\mathbf{k g})\end{array}$ & $\begin{array}{c}\text { Yield/m } \mathbf{2}^{2} \\
(\mathbf{k g})\end{array}$ \\
\hline \multirow{2}{*}{ Hybrids } & Yellow Star & $19.81 \mathrm{a}$ & $143.87 \mathrm{a}$ & $2.85 \mathrm{a}$ & $6.33 \mathrm{a}$ \\
& Red Star & $20.36 \mathrm{a}$ & $154.21 \mathrm{a}$ & $3.14 \mathrm{a}$ & $6.97 \mathrm{a}$ \\
\multirow{2}{*}{ Mulch } & Without & $15.91 \mathrm{~b}$ & $136.42 \mathrm{~b}$ & $2.17 \mathrm{~b}$ & $4.81 \mathrm{~b}$ \\
& With & $23.63 \mathrm{a}$ & $161.66 \mathrm{a}$ & $3.82 \mathrm{a}$ & $8.49 \mathrm{a}$ \\
& & & Second season $\mathbf{( 2 0 1 7 )}$ & \\
Hybrids & Yellow Star & $23.73 \mathrm{a}$ & $149.99 \mathrm{~b}$ & $3.56 \mathrm{a}$ & $7.91 \mathrm{~b}$ \\
& Red Star & $25.34 \mathrm{a}$ & $160.19 \mathrm{a}$ & $4.06 \mathrm{a}$ & $9.02 \mathrm{a}$ \\
\multirow{2}{*}{ Mulch } & Without & $20.14 \mathrm{~b}$ & $142.48 \mathrm{~b}$ & $2.87 \mathrm{~b}$ & $6.37 \mathrm{~b}$ \\
& With & $28.38 \mathrm{a}$ & $167.71 \mathrm{a}$ & $4.76 \mathrm{a}$ & $10.56 \mathrm{a}$ \\
\hline
\end{tabular}

Values having the same alphabetical letter(s) did not significantly differ at 0.05 level of probability according to Duncan's multiple range test. 
Table 5. Effect of hybrid variations and mulch on un-marketable yield of sweet pepper in 2016 and 2017 seasons.

\begin{tabular}{|c|c|c|c|c|c|}
\hline Treatment & Parameter & $\begin{array}{l}\text { Number of } \\
\text { fruits/plant }\end{array}$ & $\begin{array}{c}\text { Mean fruit } \\
\text { weight (g) }\end{array}$ & $\begin{array}{c}\text { Yield/plant } \\
\text { (g) } \\
\end{array}$ & $\begin{array}{c}\text { Yield } / \mathrm{m}^{2} \\
(\mathrm{~kg})\end{array}$ \\
\hline & & \multicolumn{4}{|c|}{ First season (2016) } \\
\hline \multirow{2}{*}{ Hybrids } & Yellow Star & $1.97 \mathrm{~b}$ & $95.99 \mathrm{a}$ & $188.91 b$ & $0.42 \mathrm{a}$ \\
\hline & Red Star & $2.47 \mathrm{a}$ & $94.05 \mathrm{a}$ & $232.35 \mathrm{a}$ & $0.52 \mathrm{a}$ \\
\hline \multirow{3}{*}{ Mulch } & Without & $2.19 a$ & $92.47 \mathrm{~b}$ & $202.73 a$ & $0.45 \mathrm{a}$ \\
\hline & With & $2.24 \mathrm{a}$ & $97.57 \mathrm{a}$ & $218.54 \mathrm{a}$ & $0.49 \mathrm{a}$ \\
\hline & & \multicolumn{4}{|c|}{ Second season (2017) } \\
\hline \multirow{2}{*}{ Hybrids } & Yellow Star & $33.38 b$ & $101.18 \mathrm{a}$ & $219.51 b$ & $0.49 \mathrm{a}$ \\
\hline & Red Star & $2.30 \mathrm{a}$ & $103.04 \mathrm{a}$ & $237.28 \mathrm{a}$ & $0.53 \mathrm{a}$ \\
\hline \multirow{2}{*}{ Mulch } & Without & $2.34 \mathrm{a}$ & $99.66 \mathrm{~b}$ & $233.50 \mathrm{a}$ & $0.51 \mathrm{a}$ \\
\hline & With & $2.14 \mathrm{a}$ & $104.52 \mathrm{a}$ & $223.31 \mathrm{a}$ & $0.49 a$ \\
\hline
\end{tabular}

Values having the same alphabetical letter(s) did not significantly differ at 0.05 level of probability according to Duncan's multiple range test.

mulch materials maintain soil moisture and raise soil temperature and consequently resulted in the maximum number of leaves and leaf area of chilli plants grown in rice straw mulch produced by wheat straw mulch and sugarcane bagasse mulch. The minimum number of leaves was recorded by the control (no mulch). Also, Norman et al. (2011) found that sawdust mulch increased hot pepper plant height more than the control.

\section{Fruit yield}

Results in Tables 4 and 5 show significant effects fort mulch treatment with higher values of all studied marketable yield traits (number of fruits/plant, mean fruit weight $(\mathrm{g})$, and yield /plant $(\mathrm{kg})$ in both seasons. However, there were no significant differences for un-marketable yield at all studied traits in both seasons, except mean fruit weigh which recorded the highest values with mulch treatment in both seasons.

These results may be due to the effect of organic mulch that resulted in maximum vegetative growth reflected on good productivity of pepper plant. In this direction, many researchers among them, Manuel et al. (2000), Thakur et al. (2000), Dauda (2011), Iftikhar et al. (2011) and Norman et al. (2011) found that organic mulch had the highest fruit yield of bell pepper grown on mulch which produced higher total number and weight of fruits than those on bare soil.

\section{Effect of the Interaction between Hybrid Variations and Organic Mulch}

\section{Vegetative growth}

Results in Table 6 show significant effects for the interaction between cultivars ('Red Star F1'and Yellow Star F1') and mulch treatments on plant height, number of leaves, leaf area, and both of plant fresh and dry weight at 75 days after transplanting in both seasons. "Red Star F1" and "Yellow Star F1" both with mulch recorded the highest values of all vegetative growth traits without significant different between them at all sampling dates in both seasons. 
SINAI Journal of Applied Sciences (ISSN: 2314-6079), Vol. (7), Is. (3), Dec. 2018

Table 6. Effect of interaction between hybrid variations and mulch on plant height, number of leaves, leaf area, plant fresh weight and plant dry weight of pepper plant in 2016 and 2017 seasons.

\begin{tabular}{|c|c|c|c|c|c|c|}
\hline Treatments & Parameters & $\begin{array}{c}\text { Plant } \\
\text { height } \\
\text { (cm) }\end{array}$ & $\begin{array}{c}\text { Number } \\
\text { of leaves/ } \\
\text { plant }\end{array}$ & $\begin{array}{c}\text { Leaf area/ } \\
\text { plant } \\
\left(\mathbf{m}^{2}\right)\end{array}$ & $\begin{array}{l}\text { Plant fresh } \\
\text { weight } \\
\text { (g) }\end{array}$ & $\begin{array}{c}\text { Plant dry } \\
\text { weight } \\
\text { (g) }\end{array}$ \\
\hline Hybrids & Mulch & \multicolumn{4}{|c|}{ First season (2016) } & \\
\hline \multirow{2}{*}{ Yellow Star } & Without & $56.02 b$ & $80.09 \mathrm{~b}$ & $19.63 b$ & $151.16 \mathrm{~b}$ & $44.55 \mathrm{c}$ \\
\hline & With & $71.48 \mathrm{a}$ & $110.33 \mathrm{a}$ & $27.83 \mathrm{ab}$ & $209.67 \mathrm{a}$ & $7.66 b$ \\
\hline \multirow{3}{*}{ Red Star } & Without & $64.52 b$ & $76.24 b$ & $22.75 b$ & $167.31 b$ & $48.03 c$ \\
\hline & With & $73.11 \mathrm{a}$ & $105.55 \mathrm{a}$ & $33.90 \mathrm{a}$ & $235.81 \mathrm{a}$ & $60.66 a$ \\
\hline & \multicolumn{6}{|c|}{ Second season (2017) } \\
\hline \multirow{2}{*}{ Yellow Star } & Without & $26.48 b$ & $83.76 \mathrm{~b}$ & $20.32 b$ & $157.08 b$ & $50.01 \mathrm{c}$ \\
\hline & With & $30.51 \mathrm{a}$ & $114.02 \mathrm{a}$ & $29.89 \mathrm{ab}$ & $218.56 \mathrm{a}$ & $3.73 b$ \\
\hline \multirow{2}{*}{ Red } & Without & $26.31 b$ & $80.35 b$ & $24.63 b$ & $173.21 b$ & $53.91 \mathrm{c}$ \\
\hline & With & $30.88 \mathrm{a}$ & $109.61 \mathrm{a}$ & $34.04 \mathrm{a}$ & $241.70 \mathrm{a}$ & $68.00 \mathrm{a}$ \\
\hline
\end{tabular}

Values having the same alphabetical letter(s) did not significantly differ at 0.05 level of probability according to Duncan's multiple range test.

This result may be due to that mulching soil may reduce water loss, therefore increase water available to plants, also, organic mulch reduce temperature on the surface soil, increase soil organic content and improve soil quality. These results are in agreement with those reported by Thakur et al. (2000) and Norman et al. (2011).

\section{Fruit yield}

Results in Tables 7 and 8 show significant effects for the interaction between hybrids and mulch treatments on all studied traits. The highest values of all marketable yield traits in both seasons were recorded with 'Red Star F1' or 'Yellow Star F1' both with mulch. As regard to the un- marketable yield results showed no significant effects for the interaction between cultivars and mulch treatment on all studied traits, except weight and number of fruits per plant in both seasons. 'Red Star F1'with or without mulch and Yellow Star F1' with mulch recorded the highest values of fruits weight and number per plant in both seasons.

The increment in total yield may be owe to that mulch treatment regulate soil moisture and temperature which led to increases in crop production of pepper. Also, mulching increased nutrient uptake. Similar results were reported by many researchers (Vos and Sumarni, 1997; Nkansah et al., 2003; Gandhi and Bains, 2006). 
Table 7. Effect of interaction between hybrid variations and mulch on marketable yield of sweet pepper plants in 2016 and 2017 seasons.

\begin{tabular}{lccccc}
\hline Parameter & $\begin{array}{c}\text { Number of } \\
\text { fruits/plant }\end{array}$ & $\begin{array}{c}\text { Mean fruit } \\
\text { weight }(\mathrm{g})\end{array}$ & $\begin{array}{c}\text { Yield } / \text { plant } \\
(\mathrm{kg})\end{array}$ & $\begin{array}{c}\text { Yield/m } \\
(\mathrm{kg})\end{array}$ \\
Treatment & & &
\end{tabular}

Hybrids Mulch

Yellow Star

Red Star

Yellow Star

Red Star without

$$
\text { With }
$$

without

$$
\text { With }
$$

without

$$
\text { With }
$$

without

With
$13.69 \mathrm{~b}$

23.29ab

$19.13 \mathrm{~b}$

$24.01 \mathrm{a}$

$18.06 \mathrm{~b}$

$28.34 \mathrm{a}$

$23.51 \mathrm{~b}$

$28.58 \mathrm{a}$
First season (2016)

$\begin{array}{lll}128.50 \mathrm{~b} & 1.76 \mathrm{~b} & 3.92 \mathrm{c} \\ 159.25 \mathrm{a} & 3.71 \mathrm{a} & 8.24 \mathrm{a} \\ 134.34 \mathrm{~b} & 2.57 \mathrm{~b} & 5.79 \mathrm{~b} \\ 164.11 \mathrm{a} & 3.94 \mathrm{a} & 8.73 \mathrm{a}\end{array}$

Second season (2017)

$\begin{array}{ccc}133.97 \mathrm{~b} & 2.42 \mathrm{~b} & 5.37 \mathrm{c} \\ 166.18 \mathrm{a} & 4.71 \mathrm{a} & 10.45 \mathrm{a} \\ 141.19 \mathrm{~b} & 3.32 \mathrm{~b} & 7.38 \mathrm{~b} \\ 169.32 \mathrm{a} & 4.84 \mathrm{a} & 10.67 \mathrm{a}\end{array}$

Values having the same alphabetical letter(s) did not significantly differ at 0.05 level of probability according to Duncan's multiple range test.

Table 8. Effect of interaction between cultivars and mulch on un-marketable yield of sweet pepper plants in 2016 and 2017 seasons.

\begin{tabular}{lccccc}
\hline Parameter & $\begin{array}{l}\text { Number of } \\
\text { fruits/plant }\end{array}$ & $\begin{array}{c}\text { Mean fruit } \\
\text { weight }(\mathrm{g})\end{array}$ & $\begin{array}{c}\text { Yield } / \text { plant } \\
(\mathrm{g})\end{array}$ & $\begin{array}{c}\text { Yield } / \mathrm{m}^{2} \\
(\mathrm{~kg})\end{array}$ \\
Treatment & & &
\end{tabular}

$\begin{array}{lll}\text { Hybrids } & \text { Mulch } & \text { First season (2016) }\end{array}$

\begin{tabular}{cccccc} 
Yellow Star & Without & $1.89 \mathrm{~b}$ & $94.82 \mathrm{a}$ & $179.12 \mathrm{a}$ & $0.39 \mathrm{a}$ \\
& With & $2.05 \mathrm{~b}$ & $97.15 \mathrm{a}$ & $198.72 \mathrm{a}$ & $0.44 \mathrm{a}$ \\
\multirow{3}{*}{ Red Star } & Without & $2.51 \mathrm{a}$ & $90.11 \mathrm{a}$ & $226.32 \mathrm{a}$ & $0.53 \mathrm{a}$ \\
& With & $2.43 \mathrm{a}$ & $97.98 \mathrm{a}$ & $238.42 \mathrm{a}$ & $0.55 \mathrm{a}$
\end{tabular}

\begin{tabular}{cccccc} 
& & \multicolumn{4}{c}{ Second season (2017) } \\
Yellow Star & Without & $2.32 \mathrm{~b}$ & $100.11 \mathrm{a}$ & $232.12 \mathrm{a}$ & $0.55 \mathrm{a}$ \\
& With & $2.02 \mathrm{~b}$ & $102.33 \mathrm{a}$ & $206.92 \mathrm{a}$ & $0.46 \mathrm{a}$ \\
\multirow{2}{*}{ Red Star } & Without & $2.15 \mathrm{a}$ & $109.01 \mathrm{a}$ & $234.84 \mathrm{a}$ & $0.52 \mathrm{a}$ \\
& With & $2.47 \mathrm{a}$ & $97.032 \mathrm{a}$ & $239.75 \mathrm{a}$ & $0.53 \mathrm{a}$
\end{tabular}

$\overline{\text { Values having the same alphabetical letter(s) did not significantly differ at } 0.05 \text { level of probability according to }}$ Duncan's multiple range test. 


\section{REFERENCES}

Ackley, W.B. (1964). Seasonal and diurnal changes in the water content and water deficit of Bartlett Pear leaves. Plant Physiol., 29:445-448.

Dauda B. M. (2011). Effects of grassed and synthetic mulching materials on growth and yield of sweet pepper (Capsicum annuum L.) in Mubi, Nigeria J. Agric. and Social Sci., 8: 97-99.

Dilipkumar, G.; Sachin, S.S. and Rajesh, K. (1990). Importance of mulch in crop production. Ind. J. Soil Conservation, 18: 20-26.

Duncan, D.B. (1958). Multiple Range and Multiple $F$ test. $2^{\text {nd }}$ Ed. McGraw-Hill, New York.

Gandhi, N. and Bains, G.S. (2006). Effect of mulching and date of transplanting on yield contributing characters of tomato. J. Res. Punjab Agric. Univ. India, 43 (1): 6-9.

Iftikhar, A.; Zahoor, H.; Shuaib, R.; Noor-Un-Nisa, M. and Summar, A.N. (2011). Response of vegetative and reproductive components of chilli to inorganic and organic mulches. Pak. J. Agric. Sci., 48 (1): 19-24.

López-Marín, J., González, A. and Gálvez, A. (2011). Effect of shade on quality of greenhouse peppers. Acta Hort., 893 : 895-900.

Malik, A.A.; Chattoo, M.A.; Sheemar, G. and Rashid, R. (2011). Growth, yield and fruit quality of sweet pepper hybrid SH-SP-5 (Capsicum annuum L.) as affected by integration of inorganic fertilizers and organic manures (FYM). J. Agric. Technol., 7: 1037-1048.
Manuel, C.P.; Allison, M.D. and Stafford, M.A.C. (2000). Comparison of organic and synthetic mulch for bell pepper production at three levels of drip irrigation. Proc. Fla. State Hort. Soc., 113: 234-236.

Nkansah, G.O.; Owusu, E.O.; Bonsu, K.O. and Dennis, E.A. (2003). Effect of mulch type on the growth, yield and fruit quality of tomato (Lycopersicon esculentum Mill). Ghana J. Hort., 3: 5564.

Norman, J.C.; Opata, J. and Ofori, E. (2011). Growth and yield of okra and hot pepper as affected by mulching. Ghana J. Hort., 9: 35-42.

Snedecor, G.W. and Cochran, W.G. (1980). Statistical Methods $7^{\text {th }}$ Ed. Iowa State Univ. Press. Ames. Iowa, USA.

Thakur, P.S.; Anju, T. and Kanaujia, S.P. (2000). Reversal of water stress effects 1.Mulching impact on the performance of Capsicum annuum $\mathrm{L}$. under water deficit. Ind. J. Hort., 57 (3): 250-254.

Venkanna, Y. (2008). Studies on the effect of mulches, organics and organic solutions on growth, yield and quality of chilli (Capsicum annum L.) cv. 'Byadagi dabbi' in northern transition zone of Karnataka. M.Sc. Thesis, Dept. Agron., Coll. Agric., Dharwad Univ. Agric. Sci., Dharwad - 580005.

Vos, J.G.M. and Sumarni, N. (1997). Integrated crop management of hot pepper (Capsicum spp.) under tropical lowland conditions. Effects of mulch on crop performance and prediction. J. Hort. Sci., 72: 415-424. 
تأثير تباين الهجن وتغطية سطح التربة بتبن القمح على النمو الخضري والمحصول الثمري للقلفل

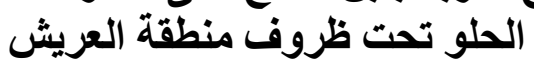

إيمان عبدالسلام جاب الله محمد، سامح عبدالحفيظ أبوالقاسم، محمود إبراهيم محمود'،

وعلي إبراهيم القصاص'

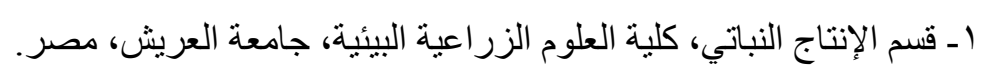

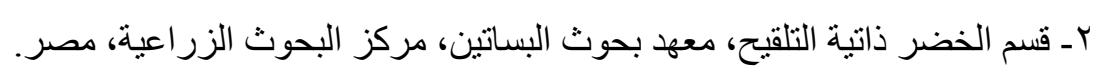

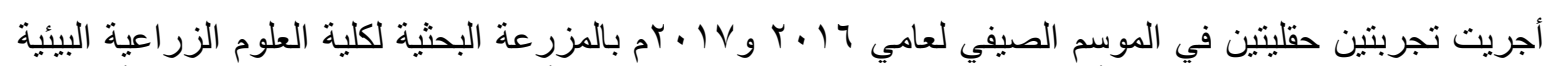

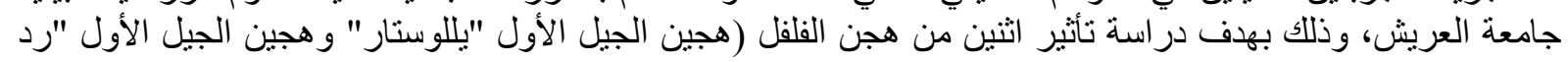

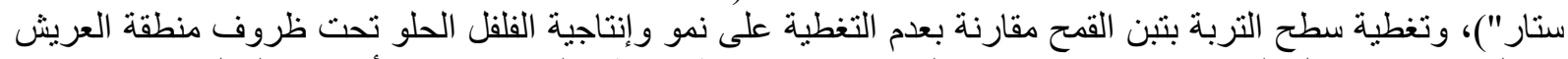

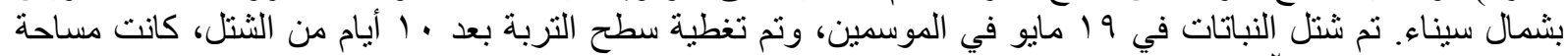

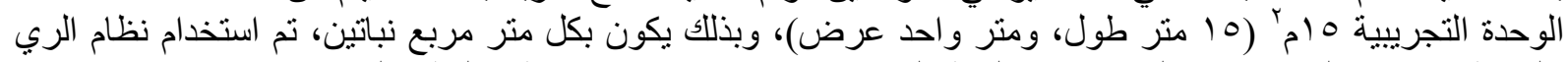

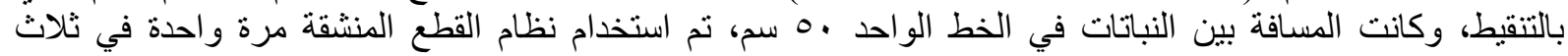

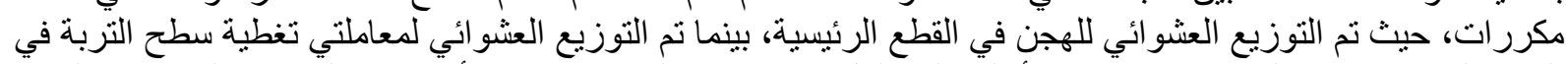

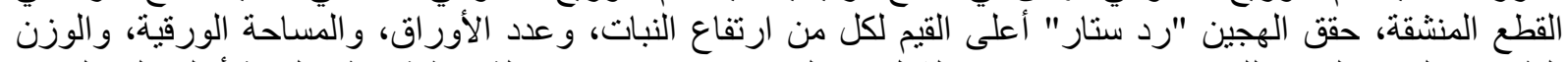

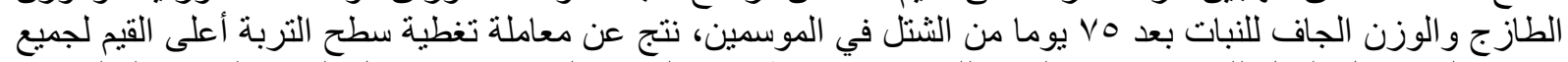

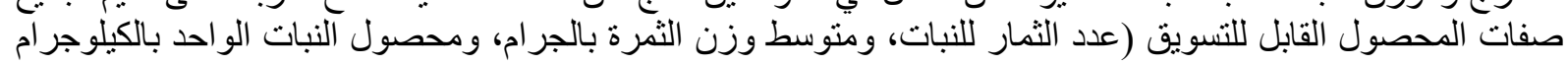

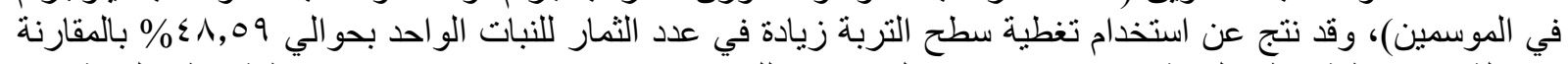

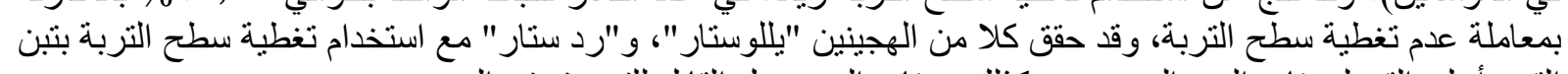

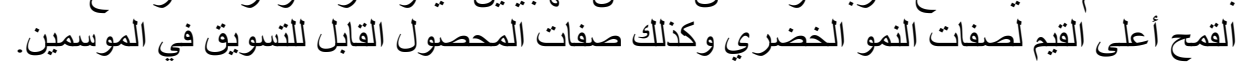

الكلمات الاسترشادية: الهجن، وتغطية، تبن القمح، النمو الخضري، المحصول الثمري، الفلفل الحلو، ظروف منطقة العريش. 